\begin{tabular}{ll}
\hline 総 説 \\
\hline
\end{tabular}

\title{
Neuropeptide Y
}

\section{一ペプチド性神経伝達物質としての作用・生合成と 神経特異的遺伝子発現調節について-}

\section{樋口宗史}

もくし

1. 緒 言 203

2.NPY によるカテコラミン遊離抑制一副腎 髄質クロマフィン細胞を用いて……………...2204

3. NPY の種々の生理作用と NPY 受容体……2 205

4. NPY 生合成機構一NPY 遺伝子構造と発 現及び NPY 生合成 ……………………22 207

5. NPY 生合成の変化一特に生体内での加龄 及び高血圧に関与しての変動. 211

6. 神経活動, シナプス伝達に伴なら NPY 遺 伝子発現の変化

7. NPY 遺伝子発現に対するホルモン, 細胞 内セカンドメッセンジャーの影響 211

8. 交感神経への分化マーカーとしての NPY 遺伝子発現.

9. 結

語.

\section{1. 緒言}

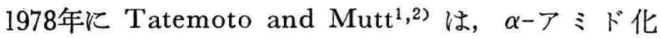
アミノ酸の二次元薄層クロマトによる同定法を確立し, それを用いてブタ小腸から $\alpha$-アミド化したペプチドで ある peptide YY (PYY) と peptide HI (PHI) を分 離した. さらに1982年, PYY の精製と同様な分離法で $\alpha$ ーアミド化された近縁ペプチドをブタ脳から分離同定 し, その脳に多量に存在するペプチドを neuropeptide Y (NPY) と命名した ${ }^{3,4}$. PYY 及び NPY はこのよ らに化学的検出法により分離同定されたペプチドである が，Edman 法による一次構造決定をしてみると，以前 に膵蔵から分離され，膵外分泌を抑制する事が知られて いた pancreatic polypeptide (PP) と極めて構造が類 似する事が見い出された ${ }^{3-5)}$. NPY, PYY, PP ともに

大阪大学医学部第一薬理学教室

（画530 大阪市北区中之島4-3-57）

原稿受理日：昭和63年12月21日（特）
36個のアミノ酸より成る， $\mathrm{C}$ 末がアミド化されたペプチ ドで, ブタ NPY の分子量は 4,254 dalton であった (図1).これら 3 つのペプチドは系統的に共通の祖先 遺伝子から派生した遺伝子の産物と考えられている ${ }^{6}$. NPY の発見に続いてその免疫組織化学的分布が詳細に 調ベられ, ラット，ヒト脳に高濃度かつ広範に（視床下 部 $>$ 線条体 $>$ 大脳皮質 $>$ 海馬 $>$ 延随 $>$ 中脳) 存在する重 要なペプチドである事が示され，それまで PP 様免疫活 性として脳に存在していると考觉られていたペプチドが 実は NPY である事が NPY の特異的抗体を用いて明 らかとなった ${ }^{7 \sim 10)}$. NPY 神経の分布で特徵的な事は,

一般的にこの神経ペプチドはカテコラミン $(\mathrm{CA})$ と共 存する事である ${ }^{9,11)}$. しかし，大脳皮質 II ～VI 層には NPY 及び NPY mRNA を発現する神経が数多く存在 し, これらは somatostatin 及び GABA と共存し, 高 次精神機能に関与している事が推察されている

例えば, Alzheimer 病ではこの NPY 神経の特徵的変 性, 脱落が括さる事が報告されている ${ }^{14)}$ ，中枢神経系で は NPY 免疫活性 (NPY-LI) は視床下部に最も大量に 存在し, 豊富な NPY 神経線維連絡が認められ, NPY は視床下部機能, 特に多くの視床下部ホルモンの遊離調 節に働いていると考兄られている（表 2 ）．末梢神経系 ではさらに明確にこのペプチドが全身の交感神経系に分 布し，GA と共存している．例えば，血管周囲交感神経 のほぼ半数に打いて NPY は CA と共存しており, 重 要な神経修飾物質あるいは cotransmitter としての作 用が考学られた ${ }^{15,16)}$ (表 3 )。このように NPY は多彩 な生理作用を持つが，1984年時点においては，はたして どこまで神経伝達物質あるいは神経修飾物質としての条 件を満たすかが不明であった。これに関して, 私達は 培養牛副腎クロマフィン細胞や培養神経細胞を用いて NPY が生理的に重要なペプチド性神経伝達物質/神経 修飾物質として働いているという知見を得た. さらに NPY 生合成が神経活動に伴い変動する事, トランス 


\section{Comparison of amino acid sequences of NPY, PYY, PP and PHI}

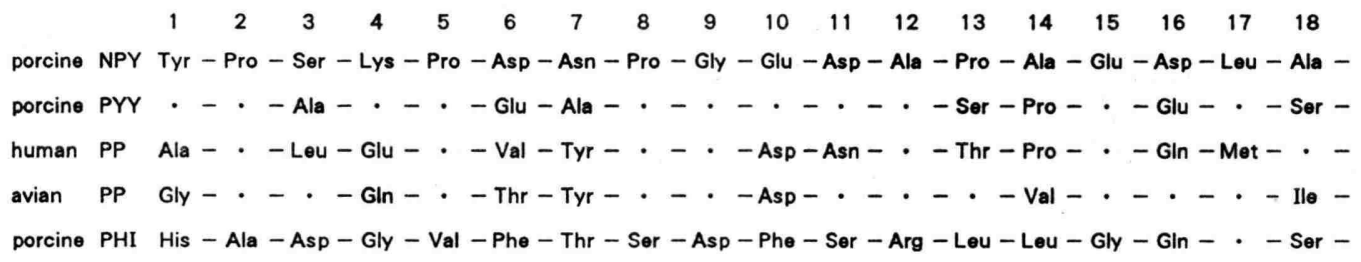

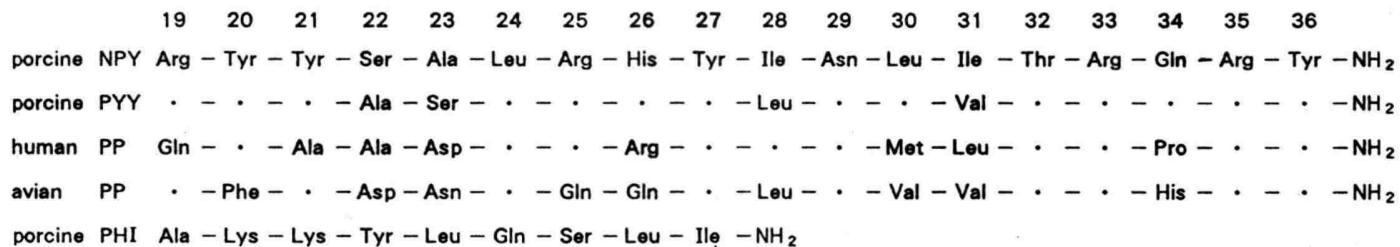

Fig. 1 Comparison of amino acid sequences of NPY, PYY, PP and PHI.

There is a marked similarity in amino acid sequence among three members (NPY, PYY and PP) of the NPY family. Amino acids identical to those in the NPY structure are indicated as dots. NPY: neuropeptide, Y PYY: peptide YY, PP: pancreatic polypeptide, $\mathrm{PHI}$ : peptide $\mathrm{HI}$.

シナプチック（transsynaptic）な調節を受ける事, in vivo においても加鈴, 高血圧病態の要因で NPY 生合 成が変動することを明らかにした．ささに NPY の生合 成は主として NPY 遺伝子発現の変動に依る事が，ク口 ーニングした NPY cDNA を用いて NPY mRNA を 定量する事で明らかになり，この神経特異的遺伝子発現 の調節機構も解明されつつある. 今回この総説では, 私 達の行なった仕事を中心に, 最近の NPY の研究につい て概説した。

\section{NPY によるカテコラミン遊離抑制一副腎髄質クロ マフィン細胞を用いて一}

NPY 免疫活性（NPY-LI）は，牛副腎においては主 としてノルエピネフリン（NE）含有クロマフィン細胞

ACh, acetylcholine; AP, activating protein; APP, avian pancreatic polypeptide; CA, catecholamine; cDNA, complementary DNA; GGRP, calcitonin gene related peptide; CPON, c-terminal peptide of NPY; Epi, epinephrine; GABA, $\gamma$-aminobutyric acid; HPP, human pancreatic polypeptide; mRNA, messenger RNA; NE, norepinephrine; NGF, nerve growth factor; NPY, neuropeptide Y; NPY-LI, neuropeptide Y-like immunoreactivity; NPY mRNA, prepro-neuropeptide Y messenger RNA; PHI, peptide HI ; PP, pancreatic polypeptide; PYY, peptide YY; TH, tyrosine hydroxylase.
に，また一部は varicose を持つ NPY 含有神経に非常 に高濃度に存在する ${ }^{17)}$. Met-enkephalin 免疫活性がエ ピネフリン (Epi ) 含有クロマフィン細胞に局在するの に比へ，対照的である. 生化学的に細胞下分布を調べる と, NPY-LI はクロマフィン細胞内のクロマフィン顆 粒に局在している17). このことは NPY 自体が分泌顆粒 からエクソサイトーシスで細胞外に放出される事を示唆 している. 実際, 牛副腎還流システムを用いて, 内藏神 経からのアセチルコリン $(\mathrm{ACh})$ がニュチニックアセチ ルコリン受容体を刺激し, クロマフィン細胞から NPY を還流液中に放出させる事が明らかになった ${ }^{18,19)}$. これ は後で述べるように, NPY 前駆体 (prepro-NPY) は 一次構造の中にシグナルペプチドを含んでおり, 他の神 経ペプチドのように, pro-NPY が粗面小胞体で合成さ れながら小胞体内腔へ移行し、ゴルジ体へ移動しながら プロセッシングを受けて，その後成熟ペプチドが分泌顆 粒から細胞外へ遊離放出されるといら概念に一致する典 型例と思われる．このように副腎髄質において NPY は $\mathrm{NE}$ 含有クロマフィン細胞分泌顆粒に存在しており, = コチニックアセチルコリン受容体刺激で, カテコラミン （CA）と共に放出されるので，この初代培養系を使らこ とは, 末梢交感神経において NE と共存する NPY の cotransmitter としての意義を研究するのに適している と考えられた. 図 2 は電気化学検出器を用いて測定し た, 培湌クロマフィン細胞からのニュチンによる内在性 

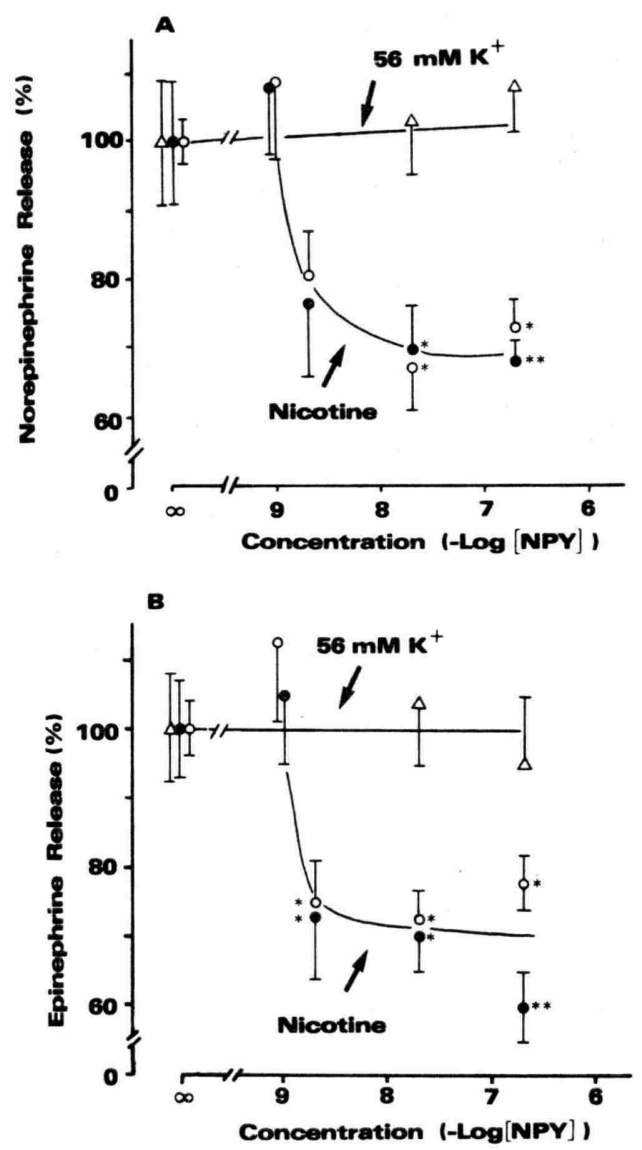

Fig. 2 Inhibition of nicotine-induced NE (A) and Epi (B) release from chromaffin cells by NPY. The release of endogeneous catecholamines from cultured chromaffin cells was induced by nicotine at $3 \times 10^{-6} \mathrm{M}$ (O) and $2 \times 10^{-5} \mathrm{M}(\bigcirc)$ or $56 \mathrm{mM} \mathrm{KGl}(\triangle)$. NPY inhibited the nicotine-stimulated $\mathrm{NE}$ and Epi release in a concentration-dependent manner. The inhibition by NPY was expressed as the percentage of the nicotine-induced catecholamine release in the presence of NPY per that in the absence of NPY. $* \mathrm{P}<0.05, * * \mathrm{P}<0.02$. (Ref. 21)

NE, Epi の遊離に対する NPY の用量作用曲線を示し ている20,21). NPY はニュチンによる NE 及び Epi 遊 離を両方とも同様に抑制した. しかし，無刺激時の基礎 的遊離あるいは高カリウムによる遊離には NPY は影 響を与えなかった。 しかも NPY のこの作用はニュチン の CA 遊離作用に対して非拮抗的に作用する事が明ら かとなった. 古典的神経伝達物質受容体が, この NPY
の $\mathrm{CA}$ 遊離抑制作用に関与しているのかを調べるた め， $\alpha-, \beta-$ ム ムスカリニックアンタゴニストを高濃度存 在させて, ニュチン誘発 $\mathbf{C A}$ 遊離に対する NPY の抑制 を調べたところ，これらのアンタゴニストが存在しても NPY の抑制作用は明らかに認められた. さらに NPY 関連ペプチドとして調ベたヒト pancreatic polypeptide (HPP), トリPP (APP), PYY の中で, HPP N NPY と同様の強い CA 遊離抑制作用が認められた. これらの ことは NPY の CA 遊離抑制作用が，特異的 NPY 受 容体を介して生じており，HPP が NPY はG末部分に 強い相同構造を持つので NPY 受容体活性化に NPY の $\mathrm{C}$ 末部分が重要である事が 推測された ${ }^{21)}$. 実際， Npropionyl [ $\left.{ }^{3} \mathrm{H}\right]-N P Y$ を用いた結合実験により牛副腎 髄質膜分画には NPY に対する特異的結合部位が存在 し,この結合部位は NPY と HPP に対して同程度の 高い親和性を有していた ${ }^{21)}$ 。このように NPY は副腎ク ロマフィン細胞上飞特異的 NPY 受容体を持ち, CA 遊 離を抑制する: その遊離抑制作用は IC50 $=2 \times 10^{-9} \mathrm{M}$ であり,これまで知られている他のペプチドによる CA 遊離抑制作用よりはるかに強いものであった（図 3,

表 1 ). NPY が副腎クロマフィン細胞に高濃度存在す るので, 内臓神経刺激により NPY は GA とともに遊 離された後, CA の遊離に生理的にネガティブフィード パックをかける事が考觉られた．NPY による同様のメ カニズムが末梢交感神経及び中枢神経における神経伝達 物質遊離抑制，つまり，シナプス前抑制をひきおこして いると思われる22 24). Håkanson らはシナプス前抑制 に関与する NPY 受容体を NPY の N末端の必要性か ら $\mathrm{Y}_{1}, \mathrm{Y}_{2}$ 飞分類できる事を示した. シナプス前抑制に は NPY 13-36 の C 末部分で十分作用が認められ， $\mathrm{Y}_{2}$ 受容体が関与していた ${ }^{24,25)}$. この NPY 受容体 $\left(Y_{2}\right.$ 受 容体) の GA 遊離抑制機構は, 百日喘菌毒素 (IAP) で 消失する.つまり $\mathrm{Y}_{2}$ 受容体は抑制性 GTP 結合蛋白質 Gi 及び少くとも 3 種類 ( $\mathrm{L}, \mathrm{T}, \mathrm{N}$ 型) の膜電位依存性 $\mathrm{Ca}$ チャンネルとカップルする GTP 結合蛋白質 Go を介して, それぞれ細胞内 cAMP 量の減少及び細胞 内への Ga イオン流入の抑制をひき括こすと考えられ $3^{26-28)}$. それ故に, NPY は他の神経伝達物質遊離抑制 作用も持ち，例えばアセチルコリンの遊離を抑制しうる 事が示された ${ }^{23,29) .}$

\section{NPY の種々の生理作用と NPY 受容体}

中枢神経系あるいは交感神経系の神経終末でのシナプ ス伝達の調節には 2 亿述べた NPY の神経伝達物質遊 
Table 1 Inhibitory effects on nicotine-induced catecholamine release from chromaffin cells by various peptides that exist in the adrenal glands

\begin{tabular}{lrrr}
\hline Peptide & Amount & (pmol/g tissue) & Effective concentration \\
\hline Neuropeptide Y & 120 & (bovine) & IC50 $=2 \times 10^{-9} \mathrm{M}$ \\
& 1500 & (rat) & \\
& 1200 & (mouse) & \\
Substance P & 4.1 & (bovine) & IC50 $=10^{-6} \mathrm{M}$ \\
& 1.2 & (rat) & \\
Met-Enk & 1.5 & (man) & \\
& 6700 & (bovine) & IC50 $=5 \times 10^{-4} \mathrm{M}$ \\
& 8.5 & (rat) & \\
Leu-Enk & 300 & $($ Guinea pig) & \\
Somatostatin & $10 \%$ of Met-Enk & IC50 $>5 \times 10^{-4} \mathrm{M}$ \\
VIP & low & & IC50 $=2 \times 10^{-5} \mathrm{M}$ \\
\hline
\end{tabular}

A large amount of neuropeptide Y (NPY) exists in the adrenal glands, and its effective dose is much smaller than those of the other peptides.

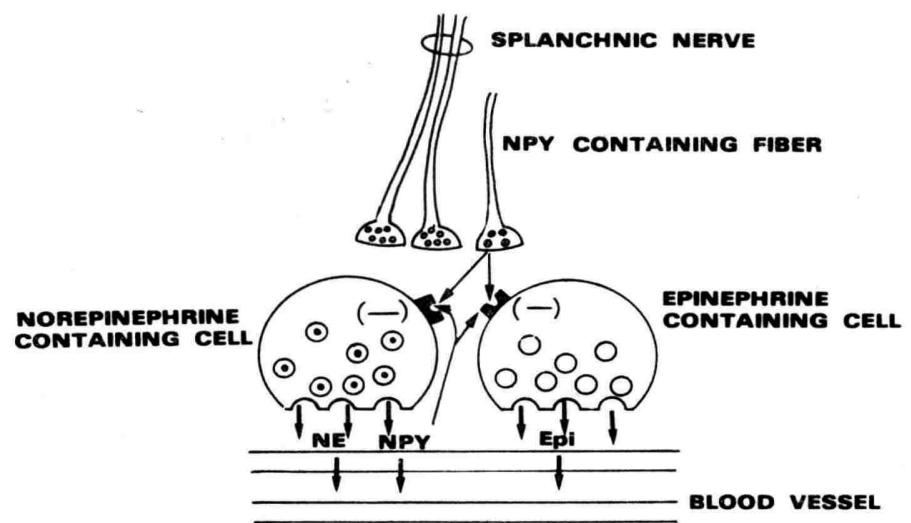

Fig. 3 Model of NPY function on catecholamine release from bovine chromaffin cells. (Ref. 21). NPY receptor, (-): Inhibition of catecholamine release.

離抑制作用が生理的に重要な役割をはたしていると思わ れる. しかし一方で，NPY はシナプス後性にも作用を 持つ ${ }^{24,25)}$. 例えぱ NPY は単独で血管平滑筋に強い収 縮を生じさせる ${ }^{16)}$. この血管平滑筋に扩ける NPY の収 縮作用は血管部位により NPY への感受性が異なり, 脳 血管は特に感受性が高い. Edvinsson ら ${ }^{16)}$ によると, 血管平滑筋における NPY のシナプス 後性の作用には NPY 単独で惹起される持続性の収縮作用之, $\alpha$ 受容体 等を介する平滑筋収縮を NPY が増強する修飾作用の 2 つが存在する. 現在, この 2 つの作用の分子レベルでの
作用機序は明らかではない，NPY のシナプス後性のこ の 2 つの平滑筋収縮增強作用は, シナプス前性のカテコ ラミン遊離抑制作用と異なり, その作用発現に NPY の 一次構造全体が 必要とされ， $\mathrm{Y}_{1}$ 受容体を介する事が示 されている ${ }^{25,30)}$. $\mathrm{Y}_{2}$ 受容体が $\mathrm{Gi}$, Go とカップルする のとは違い, $Y_{1}$ 受容体は GTP 結合蛋白質 Gp を介し てホスホリパーゼ $\mathrm{C}$ 共役し、ホスホイノシタイドの分 解を生じる事が示された ${ }^{25,30)}$; (Wahlestedt ら未発表). また NPY 受容体は $\mathrm{Na}^{+} / \mathrm{H}^{+}$交換系を活性化し, 細胞 内 $\mathrm{pH}$ をアルカリ化する事が知られている ${ }^{31)}$. しかし， 
これに関与する受容体のサブクラスや, 共役する GTP 結合蛋白質の種類に関しては現在まだ明らかでない， 表 2，3，4 N NPY の中枢，末梢作用及び病態との関 連を示している. これらの作用に NPY 受容体のどのサ ブタイプが関係しているかも今後の課題である.

\section{NPY 生合成機構 $-N P Y$ 遺伝子構造と発現及び NPY 生合成}

神経細胞に乱ける NPY がどのように生合成される かの分子生物学的研究は, 1984年に Dixon らがヒト NPY cDNA クローンをとトフェオクロモサイトーマ cDNA ライブラリーから単離した仕事に始まった ${ }^{322}$. 次いでラット NPY cDNA クローン, ヒト及びラット NPY 遺伝子クローンが単離・同定され, NPY mRNA 及び NPY 遺伝子の構造, NPY 前駆体 (prepro-NPY)

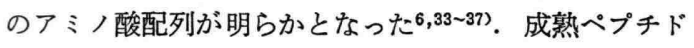
と同様, NPY 遺伝子, NPY mRNA ともに pancreatic polypeptide (PP) 遺伝子及びその mRNA と高い相 同性, 構造の類似性を持ち, 共通の祖先遺伝子から分か れたものと考学られた ${ }^{6,38)}$. ヒト及びラットの NPY 遺 伝子は Southern blot 分析で約 $8 \mathrm{~kb}$ の長さを持つ single copy gene であり, ヒト NPY 遺伝子は第 7 染 色体上飞存在する ${ }^{6,37,39)}$. pro-NPY と pro-PP を比較 して興味深い事は, プロ体の G末末部分にある G末端ペプ チドの系統的保存が著しく異なる点である.このG末端 プペチドのコード部分は NPY 遺伝子及び PP 遺伝子と も, 第 3 エキソンに存在し, pro-NPY ではG 末端ペプチ ドはヒト, ラット間で $93 \%$ の構造保存を示しており, 一 方 pro-PP では $11 \%$ の保存しか示していない、32 35,40,41). つまり，PP 遺伝子のみその第 3 エキンンが著しくモザ

Table 2

\begin{tabular}{ll}
\hline Proposed central functions of NPY & Reference \\
\hline 1. Enhancement of gonadotropin-releasing hormone (GnRH) & \\
and gonadotropins release & 69 \\
2. Elevation of circulating luteinizing hormone (LH) after & \\
steroid-treatment & 70 \\
3. Reduction of circulating LH after gonadectomy & 71 \\
4. Elevation of corticotropin-releasing factor (GRF) and & \\
circulating adrenocorticotropin (ACTH), corticosterone & \\
and aldosterone & 72,73 \\
5. Reduction of circulating growth hormone (GH) & 71 \\
6. Reduction of circulating thyrotropin (TSH) & 73 \\
7. Elevation of circulating prolactin (PRL) & 74 \\
8. Elevation of circulating vasopressin & 73 \\
9. Reduction of $\alpha$-melanotropin ( $\alpha$-MSH) release & 75 \\
10. Shift of circadian rhythms & 76 \\
11. Increase in feeding behavior & 77,78 \\
12. Decrease in systemic blood pressure & 79,80 \\
13. Enhancement of centrally evoked pressor response & 81 \\
14. Decrease and/or increase in heart rate & $80,81,82$ \\
15. Hypothermia & 82 \\
16. Bradypnea & 79,80 \\
17. Sedation & 83 \\
18. Synchronization of EEG activity & 79 \\
19. Elevation of circulating insulin & 84 \\
20. Protection against stress-induced gastric erosion & 85 \\
21. Suppression of sexual behavior & 78 \\
22. Suppression of open field and home cage activity & 86 \\
23. Suppression of grooming behavior & 82 \\
24. Inhibition of memory retention & 82 \\
\hline
\end{tabular}


Table 3

\begin{tabular}{ll}
\hline Proposed peripheral functions of NPY & Reference \\
\hline 1. Vasoconstriction & 15,16 \\
2. Potentiation of vasoconstriction & 15,16 \\
3. Increase in systemic blood pressure & 24,87 \\
4. Presynaptic inhibition (Inhibition of CA release) & $11,21,22$ \\
5. Positive and/or negative chronotropic action & 88,89 \\
6. Negative inotropic action & 90 \\
7. Goronary vasoconstriction & 90 \\
8. Inhibition of cardiac vagal action & 91 \\
9. Inhibition of colonic motility & 92 \\
10. Relaxation of colon smooth muscle & 93 \\
11. Reduction in short circuit current in gut mucosa, i.e. & \\
effects on epithelial ion transport & 94 \\
12. Inhibition of basal insulin release & 84 \\
13. Inhibition of glucose-evoked insulin release & 84 \\
14. Inhibition of stimulated glucagon release & 95 \\
15. Natriuresis & 96 \\
16. Reduction of circulating atrial natriuretic factor (ANF) & 97 \\
17. Suppression of renin secretion & 98 \\
18. Reduction of circulating vasopressin & 99 \\
19. Inhibition of contractile response in vas deferens, uterine & \\
cervix, and fallopian tube & 100 \\
20. Enhancement of stimulated thyroid hormone release & 101 \\
\hline
\end{tabular}

Table 4

\begin{tabular}{lc}
\hline $\begin{array}{c}\text { Proposed disorders and pathological conditions } \\
\text { with relation of NPY }\end{array}$ & Reference \\
\hline 1. Hypertension & 16,56 \\
2. Cardiac vasospasm & 16 \\
3. Gerebral vasospasm & 16,102 \\
4. Pheochromocytoma & 103 \\
5. Alzheimer's disease & 14 \\
6. Major depression & 104 \\
7. Parkinson's disease & 105 \\
8. Ganglioneuroblastoma & 103 \\
9. Eating disorders such as bulimia & $77,78,82$ \\
10. Schizophrenia & 106 \\
\hline
\end{tabular}

イク的進化をとげているのであるがその原因は不明であ

る. pro-NPY の上の NPY と C 末端ペプチド (GPON) の両者はその系統的保存の強さから考兄, 生理的に重要 なペプチドであると考学られる.ささらに共通祖先遺伝子 から分かれた NPY 及び PP 遺伝子の組織特異的発現の 部位は, NPY は神経細胞, PP は膵臓と極めて異なっ
ており,これらの遺伝子の組織特異的発現のメカニズム も興味深い, 私達は, NPY 遺伝子発現から成熟 NPY の生成までの生合成過程を調べる目的で, ラット NPY cDNA クローンを単離し, NPY mRNA 構造 $(0.8 \mathrm{~kb})$ を同定した ${ }^{34,35)}$ (図 4).ささらに, NPY cDNA を発現 ベクター内に挿入し, 合成 NPY mRNA を作成し, こ 


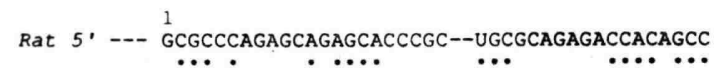

Human $5^{\prime}$---ACCCCAUCCGCUGGCUCUCACCCCUCGGAGACGCUCGCCCGACAGCAUAGUACUUGCCGCCCAGCCAC-GCC 1

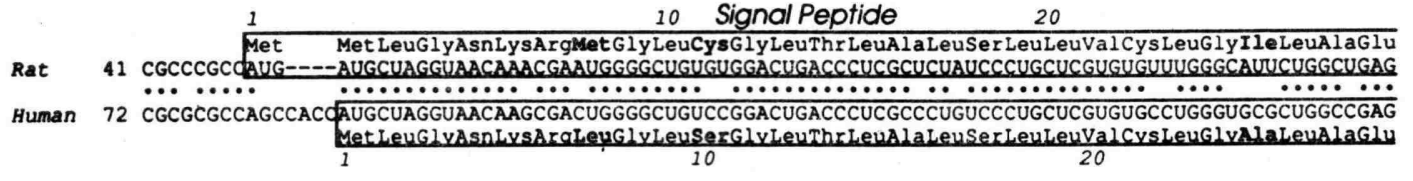

30

$40 \quad$ Neuropeptide $Y \quad 50$

G1y TyrProSerLysProAspAsnProGIyGIUAspAlaProAlaGluAspMetAlaArgTyrTyrSerAlaLeuArgHisTyrIleAsnLeuIle

Rat 133 GGCUACCCCUCCAAGCCGGACAAUCCGGGCGAGGACGCGCCAGCAGAGGACAUGGCCAGAUACUACUCCGCUCUGCGACACUACAUCAAUCUCAUC

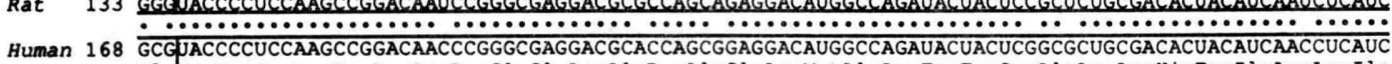

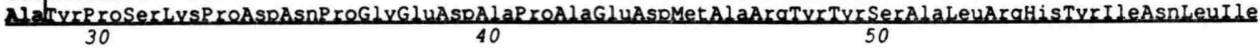

$70 \mathrm{COOH}$-Terminal Peptide 80

90

ThrArgGInArgTy G lyLysArd SerSerProGluThrLeuIleSerAspLeuLeuMetArgGluSerThrGluAsnAlaProArgThrArgLeu

Rat 229 ACCAGACAGAGAUAUGGCAAGAG JCCAGCCCUGAGACACUGAUUUCAGAUCUCUUAAUGAGAGAAAGCACAGAAAAUGCCCCCAGAACAAGGCUU

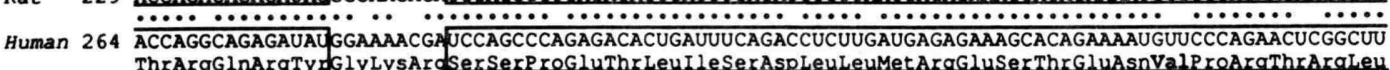

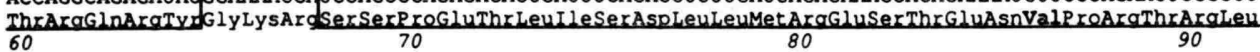

98 GluAspProserMet Trp * *

Rat 325 GAAGACCCUUCCAUGUGGUGAUGGGAAAUGAAACUUGCUCUCCUGACUUUUCCUAGUUUCCCCCCACAUCUCAUCUCAUCCUGUGAAACCAGUCUG

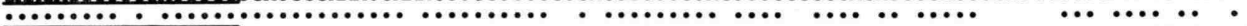

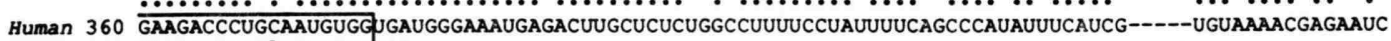
GluAspRreAlavetTrof * *

Rat 421 cCUG--UCCCACCAAUGCAUGCCACCACCAGGCUGGAUUCCGACCCAUUUCCCUUGUUGUCG---UUGUAUAUAUGUGUGUUUAAAUAAA Human 451 CACCCAUCCUACCAAUGCAUGCAgCCACUgUGCUGAAUUCUGCAAUGUUUUCCUU--UgUCAUCAUUGUAUAUAUGUGUGUUAAAUAAA

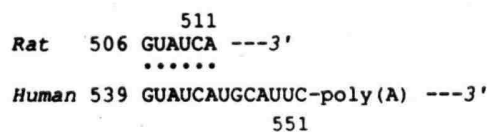

Fig. 4 Nucleotide sequence of rat brain NPY cDNA, deduced amino acid sequence of rat prepro-NPY, and comparison of rat sequences with human sequences. Identical bases in the mRNA sequences are indicated with dots. Nonidentical amino acids are indicated with bold type in both rat and human sequences. The initiating codon of the rat mRNA is presumed to be the first AUG. Triple stars indicate chain termination. The putative AAUAAA polyadenylation signals are underlined. (Refs. 34 and 35)

れをコントロールとして組織内 NPY mRNA を定量し た（表 5 ). NPY mRNA 絶対量は NPY 量とよく相 関しており, NPY mRNA 発現量を決める遺伝子の転 写等のレペルで NPY 生合成が調節されている事を示唆 していた. 中权神経系で唯一例外は NPY 量が最も高濃 度存在する視床下部に NPY mRNA が比較的少ない事 である.これは延䯣等からの外来性 NPY 神経線維が視 床下部に非常に多い事を考えれば説明がつく、興味深い 事は, 末梢組織において, 心, 肺, 脾に NPY mRNA が認められる事である. 心, 肺に拉いては内在性 NPY 神経細胞の存在 ${ }^{42}$ により説明されるが, NPY 神経細胞 の存在していない脾臓において NPY mRNA が存在す
る事は, 非神経組織での NPY 遺伝子発現を示してお り，最近 Ericsson らによって報告された巨核球におけ る NPY 遺伝子の発現43) と考台合わせ, NPY の非神経 組織に打ける生理機能の存在が考えられる.

神経細胞における NPY 遺伝子の転写は RNA ポリメ ラーゼIIにより約 $7.0 \mathrm{~kb}$ の長さの一次転写産物が作ら れる. 現在 NPY 遺伝子の転写レペルで調節機構が明ら かになりつつあるが，転写以降（post-transcriptional） での調節機構, 例えば NPY 前駆体のスプライシングの 調節機構等についての研究は進んでいない. 同様に, NPY mRNA の翻訳及びそれ以降(post-translational) の研究も始められたばかりである. Dickerson ら ${ }^{44)}$ は 
Table 5 The distribution of NPY $\mathrm{mRNA}$ and NPY immunoreactivity in rat tissues

\begin{tabular}{|c|c|c|c|c|}
\hline \multirow{2}{*}{ Tissue } & \multicolumn{2}{|c|}{ A, abundance of NPY mRNA } & \multicolumn{2}{|c|}{$\begin{array}{l}\text { B, abundance of immunoreactive } \\
\text { NPY peptide }\end{array}$} \\
\hline & $\mathrm{pg} / \mu \mathrm{g}$ RNA & $\%$ of striatum & $\mathrm{pmol} / \mathrm{g}$ tissue & $\%$ of striatum \\
\hline \multicolumn{5}{|l|}{ Central nervous system } \\
\hline Striatum & $6.1 \pm 0.9$ & 100 & $54 \pm 4 \quad(8)$ & 100 \\
\hline Frontal cortex & $5.0 \pm 0.8$ & 82 & $55 \pm 5 \quad(8)$ & 102 \\
\hline Hippocampus & 2.1 & 34 & $23 \pm 1 \quad(8)$ & 43 \\
\hline Hypothalamus & $2.0 \pm 0.1$ & 33 & $120 \pm 10 \quad(8)$ & 222 \\
\hline Medulla oblongata & 1.1 & 18 & $8 \pm 1 \quad(10)$ & 15 \\
\hline Midbrain & 0.6 & 10 & $3 \pm 1 \quad(8)$ & 6 \\
\hline Cerebellum & 0.4 & 7 & $<0.3$ & $<0.6$ \\
\hline Spinal cord & 1.8 & 30 & $7 \pm 1 \quad(6)$ & 13 \\
\hline \multicolumn{5}{|l|}{ Other tissues } \\
\hline Adrenal & 2.4 & 39 & $210 \pm 70^{\mathrm{a}}$ & 390 \\
\hline Spleen & 1.3 & 21 & $1 \pm 0.3(4)$ & 2 \\
\hline Heart & 0.7 & 11 & $27 \pm 7^{b}(4)$ & 50 \\
\hline Lung & 0.4 & 7 & $2 \pm 0.9(4)$ & 4 \\
\hline Skeletal muscle & 0.4 & 7 & NT & NT \\
\hline Stomach & 0.3 & 5 & NT & NT \\
\hline Thyroid & 0.2 & 3 & NT & NT \\
\hline Liver & 0.1 & 2 & $<0.3 \quad(4)$ & $<0.6$ \\
\hline Kidney & 0.1 & 2 & $0.8 \pm 0.4(4)$ & 1 \\
\hline Small intestine ${ }^{c}$ & 0.06 & 1 & $55 \pm 26^{\mathrm{c}} \quad(4)$ & $102^{\mathrm{c}}$ \\
\hline Testis & $<0.06$ & $<1$ & $<0.3(4)$ & $<0.6$ \\
\hline Pancreas & $<0.06$ & $<1$ & NT & NT \\
\hline
\end{tabular}

${ }^{\mathrm{a}}$ Ref. 52. ${ }^{\mathrm{b}}$ Peptide values are for atrium only, while mRNA values are for whole heart. ${ }^{\mathrm{c}}$ Peptide values are for duodenum only. High values are probably due to cross-reacting peptide YY. A. the NPY mRNA contents of total RNA preparations from various brain regions or tissues ( $\mathrm{pg} / \mu \mathrm{g}$ RNA), B. the absolute amounts of NPY immunoreactivity (pmol/g tissue), NT: not tested. (Refs. 35, 52, 53)

クローン化したヒト pro-NPY cDNA を AtT-20 マウ ス下垂体前葉細胞に安定にトランスフェクションし, pro-NPY を発現する細胞系を確立した. AtT-20 細胞 はNPY を全く発現せず, pro-ACTH/endorphin を産 生する細胞であるが，この形質転換した AtT-20 細胞 は, NPY 産生神経細胞同様, pro-NPY のプロセッシ ング産物である NPY と C 末端ペプチド (GPON)を産 生した. このプロセッシングに関与する酵素群が proACTH/endorphin のプロセッシングにも作用している 事より，2つのペプチド前駆体のプロセッシングに関与 している酵素群は互換性があり, 広く神経細胞以外飞も 存在しらる事が示唆された.

神経細胞内では NPY mRNA は細胞体存在し, 樹 状突起や軸索には認められない45)。一般に神経ペプチド は細胞体内の粗面小胞体上で mRNA から前駆体が翻
訳され，ゴルジ体でプロセッシングをうけるが，ゴルジ 体から神経線維終末部や樹状突起への輸送系の詳細は免 疫組織化学的手法の技術的な問題で明確ではない. 細胞 体で生成された NPY が軸索輸送される事は生化学的に 証明されている ${ }^{46)}$. 軸索輸送を受けた NPY は分泌顆粒 に眝蔵され，刺激に応じて分泌される47,48,17 19). NPY の分泌顆粒はいわゆる 'large dense core vesicles'に 一致し, 'small dense core vesicles' には NPY は存 在しない.つまり NPY は古典的神経伝達物質 NE の ように神経終末への再取り込みはされないと考兄られ る. 遊離された NPY は細胞外蛋白分解酵素で分解され る ${ }^{21)}$ が, NPY の分解は他の神経ペプチド程速くはな く, NPY の持続作用の一つの要因と考兄られる（ラッ 卜血漿中で半減期は 2 時間以上である (Higuchi, 未発 表)). 


\section{NPY 生合成の変化一特に生体内での加齢および高 血圧に関与しての変動}

一般に NPY mRNA 量と NPY 量がよく相関する事 より, NPY 生合成量の調節は主に NPY 遺伝子発現レ ベル（NPY mRNA 量）の調節によって行なわれてい ると思われる ${ }^{35)}$. NPY のような神経活性ペプチドが, 生体において実際に遺伝子発現レベルの調節を受けてい るのであろうか？動物に種々の薬剤処理をしたり，病 態モデルラットを用いて NPY 免疫活性量 (NPY-LI 量）の変化を測定してみると，NPY-LI 量は種々の条 件下で変動する事がわかる ${ }^{49 \sim 55)}$. 興味深い事は, 末梢及 び中枢神経系に打ける加龄による NPY 量の著しい变化 と, 血圧に関与しての NPY 量の変化（特発性高血圧症 ラット（SHR）の脳内部位での変化や，降圧剤投与で の変化等) が認められる事である. 例えぱ, 末梢蔵器で あるラット副腎に扮いて NPY 量は成熟（加齢）に伴 い, 約 200 倍も量が増加する，一方，中枢神経系におい ては加龄に伴い, 逆の調節が働いて拈り, 血圧運動中枢 の存在する延䯣・脊䯣で $1 / 10$ 亿, 線条体, 海馬で $1 / 2$ の 減少を示した. NPY の中枢投与による作用が, 著しい 降圧作用であり, 逆に末梢性には血管平滑筋の持続的収 縮をひき扣こし，その結果として強い昇圧反応を生じさ せる事から考え, NPY が加齢に伴う血圧調節に重要な 働きをしていると考兄られた ${ }^{532}$.

この加齢に伴う NPY 量の変化に NPY 遺伝子発現の 変化が関与しているかどうかを調べる目的で，ラット副 腎に打ける NPY mRNA 量を測定すると NPY 量の増 加に伴って NPY mRNA の著しい増加が抢こってい た ${ }^{54)}$ 。つまり, 生体内に执いて NPY を産生する副腎䯣 質クロマフィン細胞内で，NPY 遺伝子発現が変化し，

その結果 NPY の産生が約200倍も増加する事が明らか になった。この加龄による NPY 産生の増加は支配神経 である内臓神経の切断により消失する ${ }^{52)}$.つまり内藏神 経からのトランスシナプチック (transsynaptic) な支配 により,クロマフィン細胞の活動に何らかの変化がおこ り, それによって細胞内 NPY 遺伝子発現が調節された と考えられた. このような例はレセルピン投与における 内臟神経の活動増加が, 副腎䯣質 tyrosine hydroxylase (TH) 遺伝子の発現を増大させ, TH 分子の生合成を増

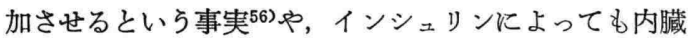
神経の活動増加が括こり NPY 遺后子発現が増大したと いら報告 ${ }^{57}$ に执いて子認められている。

生体内での”NPY ペプチドの調節は生成されるペプチ
ド量の変化だけでなく，質的にも修飾をうける，例えば ラット副腎に执いて加龄とともに Met $^{17}$ の酸化された $\operatorname{Met}(\mathrm{O})$-NPY が特異的に出現する ${ }^{53)}$. この $\operatorname{Met}(\mathrm{O})-$ NPY の出現は中枢神経系浔認められず，末梢神経節， 副腎にのみ認められる（コレシストキニン $(\mathrm{CCK})$ の $\operatorname{Met}(\mathrm{O})$ 型は中枢神経系に発現するのとは対照的であ る) が，この sulfoxide 型の生理的意義についてはま だ不明である ${ }^{53,58) .}$

\section{6. 神経活動, シナプス伝達に伴なう NPY 遺伝子発現 の変化}

内臓神経切断による NPY mRNA 量の変化は, 除神 経によるクロマフィン細胞の活動の変化が NPY 遺伝子 発現を変化させたものと考觉られる. 神経細胞活動の変 化は, 神経特異的遺伝子の発現をどのように変化させる のだろらか? 加えて NPY はカテコラミン (CA) の cotransmitter であり， CA 及び ACh の遊離を抑制す る事でシナプス伝達を変化させる. この NPY 遺伝子発 現の神経活動による調節がみい出されれば, 神経細胞自 体の持つ, 学習記憶の基盤であるシナプス可塑性の化学 的基礎現象のモデルになると考穴られた. それ故に, 培 養神経細胞を用いて, 神経活動やシナプス伝達による NPY 遺伝子発現の調節について検討を加えてみた. 最 初に種々のクローン化神経細胞をスクリーニングし, NPY mRNA を発現する細胞系をみい出した（表 6 ）. NG108-15 細胞（未分化）は NPYmRNA を最も多く 含み, NPY 遺伝子転写活性の盛んな細胞と思われる. この神経細胞を高カリウムを含んだ krebs-bicarbonate 溶液で 30 分間 $-13 \mathrm{mV}$ まで膜を脱分極させて NPY mRNA 量の変動をみた. 3 時間後に NPY mRNA は コントロールの $30 \%$ の増加を示し， 6 時間後でも $13 \%$ の 増加を示していた. actinomycin D $(5 \mu \mathrm{M})$ はこの増 加を抑制した. このことは, この神経細胞膜の脱分極シ グナルが何らかのセカンドメッセンジャーを介して核に ある NPY 遺伝子転写活性を時間オーダーで増大させる 機構がある事を示唆していた (Higuchi and Yoshida, 未発表).

7. NPY 遺伝子発現に対するホルモン, 細胞内セカン ドメッセンジャーの影響

PC12 ラットフェオクロモサイトーマ細胞はアドレナ リン性細胞系であり，NPY 遺伝子発現調節を調べる実 験に適している. 主にこの細胞を用いて, NPY mRNA 発現に対するホルモン, 伝達物質, セカンドメッセン 
Table 6 The neural cell lines which express NPY mRNA and NPY

\begin{tabular}{|c|c|c|c|}
\hline & \multicolumn{2}{|c|}{ NPY mRNA } & \multirow{2}{*}{$\frac{\mathrm{NPY}}{\mathrm{pmol} / \mathrm{g} \text { tissue }}$} \\
\hline & $\mathrm{pg} / \mu \mathrm{g}$ tcRNA & \multirow{2}{*}{$\begin{array}{c}\text { molecules/cell } \\
<0.4\end{array}$} & \\
\hline $\mathrm{C}_{6}$ rat glioma cells & $<0.05$ & & $(-)$ \\
\hline $\begin{array}{l}\text { N18TG2 mouse neuroblastoma } \\
\text { cells (inactive) }\end{array}$ & 0.13 & 0.9 & 35 \\
\hline $\begin{array}{l}\text { NG108-15 hybrid cells } \\
\text { (cholinergic) }\end{array}$ & 11.4 & 1900 & 44 \\
\hline $\begin{array}{l}\text { PG12 rat pheochromocytoma } \\
\text { cells }\end{array}$ & 0.23 & 1.9 & 19 \\
\hline $\begin{array}{l}\text { N1E115 mouse neuroblastoma } \\
\text { cells (adrenergic) }\end{array}$ & $<0.05$ & & \\
\hline AtT-20 mouse pituitary cells & $(-)$ & $(-)$ & $(-)$ \\
\hline $\begin{array}{l}\text { NGB20 hybrid cells } \\
\text { (cholinergic) }\end{array}$ & 3.2 & & 39 \\
\hline rat striatum & 6.1 & & 54 \\
\hline
\end{tabular}

ジャーの影響について調ベた ${ }^{34,35)}$. 各種ステロイドホル モン（糖質コルチコイド, 鉱質コルチコイド, 男性ホル モン, 女性ホルモン), 甲状腺ホルモン, インシュリン のらち糖質コルチコイド作用を持つステロイドホルモン のみが, NPY mRNA 量を有意に増加させた. その有 効濃度よりこの正の調節作用は, 糖質コルチコイド受容 体を介する反応であり, ラット NPY 遺伝子は糖質コル チコイド受容体により転写レベルで正に調節されると考 えられた. 実際ラット NPY 遺伝子 $5^{\prime}$ 上流領域には糖 質コルチュイド受容体に結合しらる数個の cis elements

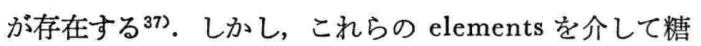
質コルチコイド受容体が NPY 遺伝子転写をどのように 調節するかについては, NPY 遺伝子プロモーター部分 と GAT (chloramphenicol transferase) ベクターの ミ二遺伝子を作成して, 直接転写活性の誘導を同定する 必要がある.

シナプス伝達に関与する神経伝達物質は種々の細胞外 刺激を細胞内セカンドメッセンジャーに変換する. 私達 はセカンドメッセンジャーとして cyclic AMP 上昇, cyclic GMP 上昇, phosphoinositides 回転に続く protein kinase $\mathrm{C}$ 活性化, 細胞内 $\mathrm{Ca}$ イオンの上昇が NPY 遺伝子発現にどう影響するのか次に検討した．細 胞内 cAMP を上昇させる forskolin, dibutyryl cAMP 処理, protein kinase $\mathrm{G}$ を活性化するフォルボールエ ステル処理, カルシウムイオノフォア (A23187) 処理
は, それぞれ単独で NPY mRNA 量を軽度増加させる 事ができた。 つまり, cAMP の上昇, protein kinase $\mathrm{C}$ の活性化, 細胞内 $\mathrm{Ca}$ 濃度の上昇は NPY 遺伝子発現 を上昇させる事を示していた ${ }^{35)}$.ささらに興味深い事は, これらの要因に著しい相乗作用 (synergistic action) が認められた事である. これらの相乗作用のうら, 細胞 内 cAMP 量の上昇と protein kinase $\mathrm{C}$ の活性化によ って最も強い相乗作用がみられた（図 5 ). つまり, 神 経細胞内で cAMP 依存性蛋白リン酸化酵素と protein kinase $\mathrm{G}$ の両方の活性上昇が生じた時, NPY 遺伝子 の著明な転写活性増大がおきる事を示唆していた。 この 相乗作用は, ヒト神経細胞 SK-N-MG 細胞でも認めら れた.つまり，ヒト及びラットの種を越えて保存される NPY 遺伝子の cis-elements (多分プロモーター領域に 存在する）が, 両リン酸化酵素活性の変化を感受し, NPY 遺伀子転写活性を変化させると考えられた.こ のことを踏まえて NPY 遺伝子 $5^{\prime}$ 上流域に検索すると 特徵的な $28 \mathrm{bp}$ のパリンドローム (palindrome) 構造 (GGGAGTCACCGGGGGGTGAGTGCG) が保存 されていた ${ }^{35)}$. この中にはいわゆる phorbol ester cis elements（T(G/T)AGTCA(G/G) あるいは CGCCAGGC) 及び cAMP cis element ((T/G)AGGTCAG) によく似た構造が含まれている. 相乗効果の合理的な可 能性として, これらの cis element に結合しうる核内 転写制御因子 (AP-1, AP-2 等59,60) ) が, cAMP 依存 


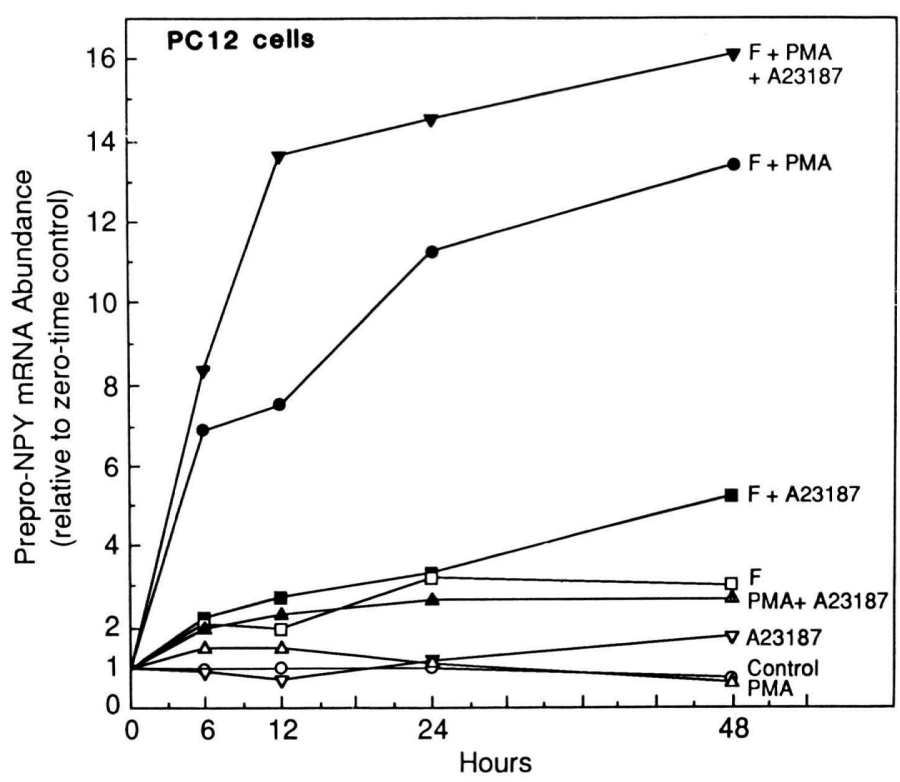

Fig. 5 Effects of forskolin, TPA, and A23187, alone or in combination, on the NPY mRNA abundance in PG12 cells. PG12 cells were treated with $20 \mu \mathrm{M}$ forskolin, $0.4 \mu \mathrm{M}$ TPA, and/or $0.4 \mu \mathrm{M}$ A23187 for the durations indicated. Forskolin (F) alone elevated NPY mRNA moderately. TPA or A23187 alone had little effect on the NPY mRNA abundance. The combination of these agents elicited the positive synergistic regulation of NPY gene expression. (Ref. 35)

性蛋白りン酸化酵素あるいは protein kinase C ヒより リン酸化される事で，NPY 遺伝子転写を行なう RNA ポリメラーゼII 活性を相乗的に増加できるようになる事 が考兄られる。このようなセカンドメッセンジャ一間の 遺伝子発現に括ける著しい相乗作用は, 詳細が不明でこ れまで報告がほとんどなされていないが，遺伝子発現調 節では重要な機構であると思われる.

上記のように, 神経活動やシナプス伝達により細胞内 セカンドメッセンジャーが変動すると, NPY 遺伝子発 現は著しく変化する事が明らかとなった。この NPY $\mathrm{mRNA}$ 量の変化は NPY 生成量の変動をきたし，力 テュラミン等によるシナプス伝達の修飾に変動をもたら す. 要するに神経伝達物質レベルでのシナプス可塑性の 1 つのモデルになると思われた．

\section{8. 交感神経への分化マーカーとしての NPY 遺伝子} 発現

多くの免疫組織化学の研究により NPY は末梢交感神 経系, 中枢カテコラミン (CA 神経に主に共存する事が わかっている ${ }^{9,11)}$ 。つまり，CA 合成酵素群の誘導がおき
ている神経細胞内に，NPY 産生が和きる事を示してい る. それ故に, この NPY 生合成のメカニズムとして, $\mathrm{CA}$ 神経細胞内での NPY 遺伝子転写活性の出現, calcitonin/GGRP でみられるような選択的スプライシ ング (alternative splicing) の発現, あるいは翻訳レ ベルでの生合成増加等が考光られた。この NPYの CA 神経細胞内での特異的発現の機構を検討する目的で, 種々のクローン化神経細胞をスクリーニングした．例党 ば, Nirenberg 研で確立されたマウス神経細胞, 雑種 神経細胞, ラット PC12 フェオクロモサイトーマ細胞, マウス AtT-20 下垂体細胞, グリオーマ細胞, マクロ ファージ等多くの細胞が調べられた（これらの神経細胞 は, 神経伝達物質含量や，生合成律速酵素量が測定さ れ 分類されている.).このうち, NPY を発現する細 胞は神経細胞に限られていたが，予想に反して未分化ア セチルコリン (ACh) 含有神経細胞 NG108-15 細胞,

NCB-20 細胞浶子多量の NPY が, 一方未分化 CA 含有神経細胞 PC12 細胞, N1E115 細胞には少量の NPY が存在するのが明らかとなった（表 6 ）、NPYを 産生する細胞には Northern blot 分析で, 脳内に認め 


\section{PC12 cells}

\section{S- $18 \mathrm{~S}-$ \\ $0.8 \mathrm{~kb}-$ \\ C D N DN \\ 1 day

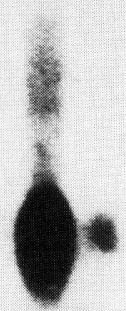

Fig. 6 Long-term effects of NGF on the NPY mRNA abundance. PC12 cells were treated with $60 \mathrm{ng} / \mathrm{ml} \mathrm{NGF}(\mathrm{N})$ and/or $1 \mu \mathrm{M}$ dexamethasone (D). The total cellular RNA was analyzed electrophoretically, and Northern blot membranes were hybridized with a nick-translated rat NPY cDNA probe. NGF or dexamethasone alone elevated NPY mRNA abundance remarkably, while dexamethasone diminished the effect of NGF when both were present.

(Higuchi and Sabol, unpublished data)

られるものと同じ $0.8 \mathrm{~kb}$ の成熟 NPY mRNA が認め られ, 明らかに未分化 ACh 含有細胞湟多に存在し ていた（表6)。このことは NPYは一般に CA の cotransmitter として認められているが，細胞レベルに 打いて CA の発現と NPY 遺伝子発現とは一致しない 場合がある事を示していた．多分，NPY 遺伝子発現に は, $\mathrm{CA}$ 生合成酵素群の遺伝子発現とは違う転写因子が 関与している事を示唆している.

しかし，これらの未分化神経細胞をPC12 細胞は 2.5S 神経成長因子 (NGF) で交感神経様細胞飞 ${ }^{61)}$, ま た NG108-15 細胞あるいは NCB-20 細胞は cAMP や DMSO で ACh 性神経細胞飞 ${ }^{62)}$ 分化させると, PC12 細胞では 4 日間で NPY mRNA 量が未分化型の 100 倍 に増加し（図6 ），NG108-15 細胞では逆に分化に伴 い, NPY mRNA 量が 3 日間で $1 / 10$ 亿減少した。ささら に nuclear run-on experiment により NGF による PC12 細胞分化時の NPY 遺伝子転写活性の变化を調 べると, 明らかに核での NPY 遺伝子の転写活性が増大 していた (Higuchi and Sabol, 未発表)。一般に真核
細胞遺伝子転写制御飞は TATA ボックスや CCAAT ボックスに結合する基本的に必須の転写活性因子以外に もプロモーター部位に結合する何種類かの細胞特異的 transacting factor が存在すると考兄られる。このよ らにモデル神経細胞を用いた時, 交感神経細胞分化時に は，NPY 遺伝子発現を強める転写因子の誘導あるいは 転写抑制因子の産生抑制が拈こっている事を示唆してい た. また ACh 性神経細胞分化時に扔いては，上と逆の 現象が生じていると考觉られた。

交感神経に NPY が発現する機構をさらに検討する ために，PG12 細胞にお抢る NGF の NPY mRNA 発 現増大を詳細に調べた (Higuchi and Sabol, 未発表). PC12 細胞は NGF に上る分化に伴い, 形態的にも生 化学的にも多くの変化が执こる63.. protooncogene を 含め幾つかの遺伝子発現の増加も NGF 処理の PG12 細胞において観察されている ${ }^{64-68)}$ 。これらの変化に比 べ，NGF による NPY mRNA の増加は最も顕著なも のである。 NPY mRNA の増加は NGF 添加後, 3.5 時間で13倍にも達し, NGF による遺伝子発現の誘導の 
うちでも初期に属するものである。しかし，この増加は 蛋白合成阻害剂で抑制される事より，NGF による何ら かの蛋白性転写因子の産生を介する 2 次的なるのと考兄 られる (Higuchi and Sabol, 未発表). 例えぱ c-fos 遺伝子発現誘導は蛋白合成阻害剂で抑制されず, NGF の最も直接的な作用と考学られるが，c-fos 遺伝子産物 が NPY 遺伝子発現に関与しているかは現在不明のまま である ${ }^{65)}$. Minth ら ${ }^{6)}$ は, 神経細胞内で NPY 遺伝子が 発現する時に必須のプロモーター部位はヒト NPY 遺伝 子では $-530 \mathrm{bp}$ の $5^{\prime}$ 上流領域と 51 bp の第 1 エキン ンの最初の部分にある事を示した. しかし, 神経細胞の 分化（特に交感神経への分化）に関与する transacting factor を認識する cis elements がこれらの部位に存在 するかどうかは不明のままである. NGF は交感神経の 分化や神経細胞の生存維持に必須の因子として知られ,

いろいろな分化・増殖に関与する遺伝子の転写活性を上 昇させる事が知られていたが，その機構については詳細 が不明のままであった. NGF による NPY 遺伝子発 現増大の現象の研究は, NGF の作用機序の解明に良い 手がかりを与えると思われる.

\section{9. 結 語}

neuropeptide Y (NPY) は中枢及び末梢交感神経系 に広く分布し，降圧作用を含む多様な中枢神経作用や血 管平滑筋収縮作用, 神経終末よりの GA 遊離抑制作用 を持つ.これらの生理作用を発現する NPY 受容体にも 少なくとも 2 つのザタイプ $\left(\mathrm{Y}_{1}, \mathrm{Y}_{2}\right)$ があり, 種々の GTP 結合蛋白質とカップルする事がわかってきた. cDNA 及び遺伝子クローニングや構造決定によりヒト 及びラットの NPY 前駆体一次構造が決定され, その強 い系統的構造保存から NPY は生体に基本的な生理作用 を持つペプチド性神経伝達物質と考えられ，それを支持 する知見が集積してきている.NPY の多彩な生理作用 に比べ, NPY 遺伝子発現や, pro-NPY の生合成, プロ セッシング, 分解に関する知見は少なかった. 私達の実 験により, NPY 遺伝子発現及び生合成は神経活動, ホ ルモン, 神経伝達物質受容体を介するセカンドメッセン ジャーにより強く調節されている事が明らかとなった. これらの因子による NPY 遺伝子発現調節は, NPY の 生理作用より考宎, シナプス伝達の変動をきたし, シナ プス可塑性の 1 つの良い生化学的モデルと考えられた. さらに NPY は交感神経細胞内に発現し, また, CA 性 神経細胞分化時の $N P Y$ 遺伝子発現が著明に増大する 事から, この遺伝子発現調節機構の研究は, 交感神経分
化の機序解明の良い手かがりを与兄ると考兄られた.

謝辞 : 研究の御指導をいただいた吉田博教授, ならびに 米国国立衛生研究所 (NIH) 飞おいて共同研究をしてい ただいた Hsiu-Ying T. Yang 博士, Erminio Costa 博士, Steven L. Sabol 博士, Marshall Nirenberg 博士に深謝いたします.

\section{文献}

1) Tatemoto, K. and Mutt, V.: Proc. Natl. Acad. Sci. U.S.A. 75, 4115 (1978)

2) Tatemoto, K. and Mutt, V.: Nature 285, 417 (1980)

3) Tatemoto, K., Garlquist, M. and Mutt, V.: Nature 296, 659 (1982)

4) Tatemoto, K.: Proc. Natl. Acad. Sci. U.S.A. 79, 5485 (1982)

5) Kimmel, J.R., Hayden, L.J. and Pollock, H.G.: J. Biol. Chem. 250, 9369 (1975)

6) Minth, C.D., Andrews, P.G. and Dixon, J.E.: J. Biol. Chem. 261, 11974 (1986)

7) Adrian, T.E., Allen, J.M., Bloom, S.R., Ghatei, M.A., Rossor, M.N., Roberts, G.W., Crow, T.J., Tatemoto, K. and Polak, J.M.: Nature 306, 584 (1983)

8) Allen, Y.S., Adrian, T.E., Allen, J.M., Tatemoto, K., Grow, T.J., Bloom, S.R. and Polak, J.M.: Science 221, 877 (1983)

9) Everitt, B.J., Hökfelt, T., Terenius, L., Tatemoto, K., Mutt, V. and Goldstein, M.: Neuroscience 11, 443 (1984)

10) DiMaggio, D.A., Chronwall, B.M., Buchanan, K. and O'Donohue, T.L.: Neuroscience 15, 1149 (1985)

11) Lundberg, J.M., Terenius, L., Hökfelt, T., Martling, C.R., Tatemoto, K., Mutt, V., Polak, J.M., Bloom, S. and Goldstein, M.: Acta Physiol. Scand. 116, 477 (1982)

12) Hendry, S.H.C., Jones, E.G., DeFelipe, J., Schmechel, D., Brandon, C. and Emson, P.C.: Proc. Natl. Acad. Sci. U.S.A. 81, 6526 (1984)

13) Terenghi, G., Polak, J.M., Hamid, Q., O'Brien, E., Denny, P., Legon, S., Dixon, J., Minth, C.D., Palay, S.L., Yasargil, G. and Chan-Palay, V.: Proc. Natl. Acad. Sci. U.S.A. 84, 7315 (1987)

14) Kowall, N.W. and Beal, M.F.: Ann. Neurol. 23, 105 (1988)

15) Emson, P.C. and DeQuidt, M.E.: TINS 7, 31 (1984)

16) Edvinsson, L.,, Håkanson, R., Wahlestedt, C. and Uddman, R.: TIPS 8, 231 (1987)

17) Majane, E.A., Alho, H., Kataoka, Y., Lee, 
C.H. and Yang, H.-Y.T.: Endocrinology 117, 1162 (1985)

18) Allen, J.M., Bircham, P.M.M., Bloom, S.R. and Edwards, A.V.: J. Physiol. 357, 401 (1984)

19) Hexum, T.D., Majane, E.A., Russett, L.R. and Yang, H.-Y.T.: J. Pharmacol. Exp. Ther. 243, 927 (1987)

20) Higuchi, H., Costa, E. and Yang. H.-Y.T.: Fed. Proc. 46, 1448 (1987)

21) Higuchi, H., Costa, E. and Yang, H.-Y.T.: J. Pharmacol. Exp. Ther. 244, 468 (1988)

22) Lundberg, J.M. and Stjärne, L.: Acta Physiol. Scand. 120, 477 (1984)

23) Colmers, W.F., Lukowiak, K. and Pittman, Q.J.: J. Physiol. 383, 285 (1987)

24) Håkanson, R., Wahlestedt, C., Ekblad, E., Edvinsson, L. and Sundler, F.: Prog. Brain Res. Vol. 68, Edited by Hökfelt, T., Fuxe, K. and Pernow, B., p. 279, Elsevier Science Publishers, Amsterdam (1986)

25) Hảkanson, R. and Wahlestedt, C.: IBRO Meeting Abstr. S679 (1987)

26) Fredholm, B.B., Jansen, I. and Edvinsson, L. : Acta Physiol. Scand. 124, 467 (1985)

27) Kassis, S., Olasmaa, M., Terenius, L. and Fishman, P.H.: J. Biol. Chem. 262, 3429 (1987)

28) Ewald, D.A., Sternweis, P.C. and Miller, R.J.: Proc. Natl. Acad. Sci. U.S.A. 85, 3633 (1988)

29) Stretton, C.D. and Barnes, P.J.: Br. J. Pharmacol. 93, 672 (1988)

30) Wahlestedt, G., Yanaihara, N. and Hảkanson, R.: Regul. Pept. 13, 307 (1986)

31) Clark, J.D. and Limbird, L.E.: Fed. Proc. 47, A783 (1988)

32) Minth, C.D., Bloom, S.R., Polak, J.M. and Dixon, J.E.: Proc. Natl. Acad. Sci. U.S.A. 81, 4577 (1984)

33) Higuchi, H. and Sabol, S.L.: Fed. Proc. 46, 2182 (1987)

34）桶口宗史, Sabol, S.L.: 神経化学 26, 58 (1987)

35) Higuchi, H., Yang, H.-Y.T. and Sabol, S.L.: J. Biol. Chem. 263, 6288 (1988)

36) Allen, J., Novotný, J., Martin, J. and Heinrich, G.: Proc. Natl. Acad. Sci. U.S.A. 84, 2532 (1987)

37) Larhammar, D., Ericsson, A. and Persson, H.: Proc. Natl. Acad. Sci. U.S.A. 84, 2068 (1987)

38) Leiter, A.B., Montminy, M.R., Jamieson, E. and Goodman, R.H.: J. Biol. Chem. 260, 13013 (1985)

39) Takeuchi, T., Gumucio, L.D., Yamada, T., Meisler, M.H., Minth, C.D., Dixon, J.E., Eddy, R.E. and Shows, T.B.: J. Clin. Invest. 77,
1038 (1986)

40) Boel, E., Schwartz, T.W., Norris, K.E. and Fiil, N.P.: EMBO J. 3, 909 (1984)

41) Yamamoto, H., Nata, K. and Okamoto, H.: J. Biol. Chem. 261, 6156 (1986)

42) Gu, J., Polak, J.M., Allen, J.M., Huang, W.M., Sheppard, M.N., Tatemoto, K. and Bloom, S.R.: J. Histochem. Gytochem. 32, 467 (1984)

43) Ericsson, A., Schalling, M., McIntyre, K.R., Lundberg, J.M., Larhammar, D., Seroogy, K., Hökfelt, T. and Persson, H.: Proc. Natl. Acad. Sci. U.S.A. 84, 5585 (1987)

44) Dickerson, I.M., Dixon, J.E. and Mains, R.E.: J. Biol. Chem. 262, 13646 (1987)

45) Chan-Palay, V., Yasargil, G., Hamid, Q., Polak, J.M. and Palay, S.L.: Proc. Natl. Acad. Sci. U.S.A. 85, 3213 (1988)

46) Fried, G., Lundberg, J.M. and TheodorssonNorheim, E.: Acta Physiol. Scand. 125, 145 (1985)

47) Pelletier, G., Guy, J., Allen. Y.S. and Polak, J.M.: Neuropeptides 4, 319 (1984)

48) Bastiaensen, E., Miserez, B. and De Potter, W.: Brain Res. 442, 124 (1988)

49) Lundberg, J.M., Saria, A., Hökfelt, T., FrancoCereceda, A. and Terenius, L.: Acta Physiol. Scand. 123, 363 (1985)

50) Nagata, M., Franco-Cereceda, A., Svensson, T. and Lundberg, J.M.: Acta Physiol. Scand. 128, 321 (1986)

51 ) Allen, J.M., Schon, F., Yeats, J.C., Kelly, J.S. and Bloom, S.R.: Neuroscience 19, 1251 (1986)

52) Higuchi, H. and Yang, H.-Y.T.: J. Neurochem. 46, 1658 (1986)

53) Higuchi, H., Yang, H.-Y.T. and Costa, E.: J. Neurochem. 50, 1879 (1988)

54) 桶口宗史, 岩佐 厚, 吉田 博 : 神経化学 27, 276 (1988)

55) Maccarrone, C. and Jarrott, B.: Brain Res. 345,165 (1985)

56) Biguet, N.F., Buda, M., Lamouroux, A., Samolyk, D. and Mallet, J.: EMBO J. 5, 287 (1986)

57) Fischer-Colbrie, R., Iacangelo, A. and Eiden, L.E.: Proc. Natl. Acad. Sci. U.S.A. 85, 3240 (1988)

58) O'Hare, M.M.T., Tenmoku, S., Aakerlund, L., Hilsted, L., Johnsen, A. and Schwartz, T.W.: Regul. Pept. 20, 293 (1988)

59) Angel, P., Imagawa, M., Chiu, R., Stein, B., Imbra, R.J., Rahmsdorf, H.J., Jonat, C., Herrlich, P. and Karin, M.: Cell 49, 729 (1987)

60) Roesler, W.J., Vandenbark, G.R. and Hanson, R.W.: J. Biol. Chem. 263, 9063 (1988) 
61) Greene, L.A. and Tischler, A.S.: Proc. Natl. Acad. Sci. U.S.A. 73, 2424 (1976)

62) Nirenberg, M., Wilson, S., Higashida, H., Rotter, A., Krueger, K., Busis, N., Ray, R., Kenimer, J.G. and Adler, M.: Science 222, 794 (1983)

63) Guroff, G.: Cell Culture in the Nervous System, Edited by Bottenstein, J.E. and Sato, G., p. 245, Plenum Press, New York (1985)

64) Greenberg, M.E., Greene, L.A. and Ziff, E.B.: J. Biol. Chem. 260, 14101 (1985)

65) Milbrandt, J.: Proc. Natl. Acad. Sci. U.S.A. 83, 4789 (1986)

66) Dickson, G., Prentice, H., Julien, J.-P., Ferrari, G., Leon, A. and Walsh, F.S.: EMBO J. 5, 3449 (1986)

67) Feinstein, S.C., Dana, S.L., McConlogue, L., Shooter, E.M. and Foffino, P.: Proc. Natl. Acad. Sci. U.S.A. 82, 5761 (1985)

68) Leonard, D.G.B., Ziff, E.B. and Greene, L.A.: Mol. Cell. Biol. 7, 3156 (1987)

69) Khorram, O., Pau, K.-Y.F. and Spies, H.G.: Peptides 9, 411 (1988)

70) Allen, L.G., Crowley, W.R. and Kalra, S.P.: Endocrinology 212, 1953 (1987)

71) McDonald, J.K., Lumpkin, M.D., Samson, W.K. and McGann, S.M.: Proc. Natl. Acad. Sci. U.S.A. 82, 561 (1985)

72) Haas, D.A. and George, S.R.: Life Sci. 41, 2725 (1987)

73) Härfstrand, A., Fuxe, K., Agnati, L.F., Eneroth, P., Zini, I., Zini, M., Andersson, K., Von Euler, G., Terenius, L., Mutt, V. and Goldstein, M.: Neurochem. Int. 8, 355 (1986)

74) Kerkerian, L., Guy, J., Lefèvre, G. and Pelletier, G.: Peptides 6, 1201 (1985)

75) Danger, J.M., Guy, J., Benyamina, M., Jégou, S., Lembuolenger, S., Coté, J., Tonon, M.C., Pelletier, G. and Vaudry, H.: Peptides 6, 1225 (1985)

76) Albers, H.E., Ferris, C.F., Leeman, S.E. and Goldman, B.D.: Science 223, 833 (1984)

77) Clark, J.T., Kalra, P.S., Crowley, W.R. and Kalra, S.P.: Endocrinology 115, 427 (1984)

78) Clark, J.T., Kalra, P.S. and Kalra, S.P. : Endocrinology 117, 2435 (1985)

79) Fuxe, K., Agnati, L.F., Härfstrand, A., Zini, I., Tatemoto, K., Pich, E.M., Hökfelt, T., Mutt, V. and Terenius, L.: Acta Physiol. Scand. 118, 189 (1983)

80) Härfstrand, A.: Acta Physiol. Scand. 128, 121 (1986)

81) Lightman, S.L. and Vallejo, M.: J. Physiol. 371, 96p (1985)

82) Gray, T.S. and Morley, J.E.: Life Sci. 38, 389
(1986)

83 ) Zini, I., Pich, M., Fuxe, K., Lenzi, P.I., Agnati, L.F., Härfstrand, A., Mutt, V., Tatemoto, K. and Moscara, M.: Acta Physiol. Scand. 122, 71 (1984)

84) Moltz, J.H. and McDonald, J.K.: Peptides 6, 1155 (1985)

85) Heilig, M. and Murison, R.: Eur. J. Pharmacol. 137, 127 (1987)

86) Heilig, M. and Murison, R.: Regul. Pept. 19, 221 (1987)

87) Dahlöf, C., Dahlöf, P. and Lundberg, J.M. : Eur. J. Pharmacol. 109, 289 (1985)

88) Wahlestedt, C., Wohlfart, B. and Hảkanson, R.: Acta Physiol. Scand. 129, 459 (1987)

89) Balasubramaniam, A., Grupp, I., Matlib, M.A., Benza, R., Jackson, R.L., Fischer, J.E. and Grupp, G.: Regul. Pept. 21, 289 (1988)

90 ) Allen, J.M., Bircham, P.M.M., Edwards, A.V., Tatemoto, K. and Bloom, S.R.: Regul. Pept. 6, 247 (1983)

91) Potter, E.K.: Neurosci. Lett. 54, 117 (1985)

92) Hellström, P.M., Olerup, O. and Tatemoto, K.: Acta Physiol. Scand. 124, 613 (1985)

93) Wiley, J. and Owyang, C.: Proc. Natl. Acad. Sci. U.S.A. 84, 2047 (1987)

94) Cox, H.M., Cuthbert, A.W., Håkanson, R. and Wahlestedt, C.: J. Physiol. 398, 65 (1988)

95) Pettersson, M., Lundquist, I. and Ahrén, B.: Endocrine Res. 13, 407 (1987)

96) Allen, J.M., Raine, A.E.G., Ledingham, J.G.G. and Bloom, S.R.: Glin. Sci. 68, 373 (1985)

97) Baranowska, B., Gutkowska, J., Lemire, A., Cantin, M. and Genest, J.: Biochem. Biophys. Res. Commun. 145, 680 (1987)

98) Hackenthal, E., Aktories, K., Jakobs, K.H. and Lang, R.E.: Am. J. Physiol. 252, F543 (1987)

99) Aubert, J.F., Burnier, M., Waeber, B., Nussberger, J., Dipette, D.J., Burris, J.F. and Brunner, H.R.: J. Pharmacol. Exp. Ther. 244, 1109 (1988)

100) Stjernquist, M., Emson, P., Owman, C., Sjöberg, N.-O., Sundler, F. and Tatemoto, K.: Neurosci. Lett. 39, 279 (1983)

101) Grunditz, T., Håkanson, R., Rerup, C., Sundler, F. and Uddman, R.: Endocrinology 115, 1537 (1984)

102) Allen, J.M., Schon, F., Todd, N., Yeats, J.C., Crockard, H.A. and Bloom, S.R.: Lancet ii, 550 (1984)

103) Adrian, T.E., Allen, J.M., Terenghi, G., Bacarese-Hamilton, A.J., Brown, M.J., Polak, J.M. and Bloom, S.R.: Lancet ii, 540 (1983) 104) Heilig, M., Wahlestedt, C., Ekman, R. and 
Widerlöv, E.: Eur. J. Pharmacol. 147, 465 (1988)

105) Allen, J.M., Cross, A.J., Grow, T.J., JavoyAgid, F., Agid, Y. and Bloom, S.R.: Brain
Res. 337, 197 (1985)

106) Beal, M.F., Svendsen, C.N., Bird, E.D. and Martin, J.B.: Neurochem. Pathol. 6, 169 (1987)

\begin{abstract}
Neuropeptide Y (NPY): Functions and biosynthesis as a peptidergic neurotransmitter and the regulation of neuron-specific expression of NPY gene. Hiroshi HIGUCHI (Department of Pharmacology I, Osaka University School of Medicine, Nakanoshima, Kita-ku, Osaka 530, Japan). Folia pharmacol. japon. 93, 203 218 (1989)

Neuropeptide Y (NPY) is widely distributed in the central and sympathetic nervous systems and has a variety of central actions including regulation of blood pressure and peripheral actions; e.g., continuous vasoconstriction and inhibition of catecholamine release. The NPY receptor can be divided into 2 subclasses $\left(Y_{1}, Y_{2}\right)$, and these subclasses are coupled to GTP binding proteins ( $\mathrm{Gi}$, Go, Gp ….). Recently, human and rat prepro-NPY mRNA and NPY gene structures have been determined by cDNA and genomic cloning and sequencing. The strong evolutionary conservation of these structures suggested that NPY is an essential peptidergic neurotransmitter. Little is known about the biosynthesis, processing, degradation of NPY and NPY gene expression. We showed that NPY gene expression and NPY biosynthesis are regulated by neural activity, hormone, and intracellular second messengers via neurotransmitter receptors. The change of NPY gene expression by these neural factors is considered to be a good model for a synaptic plasticity, because these changes cause the changes of synaptic transmission. Furthermore, because NPY is expressed in sympathetic neurons and its gene expression increased markedly on the differentiation of adrenergic cells, this study about NPY gene expression could provide good clues for elucidating the differentiation of sympathetic neurons.
\end{abstract}

